\section{Comparison of Voluntary Feed Intake and Venom Production of Wild and Laboratory Bred Sand Vipers}

\author{
Bogdan Georgescu - Gheorghe Sălăjan - Daniel \\ Mierliță - Doina Iozon - Antonia Odagiu
}

University of Agricultural Sciences and Veterinary Medicine, Cluj-Napoca

\section{SUMMARY}

The study was performed on vipers of the Vipera ammodytes ammodytes species and aimed to establish the differences in voluntary feed intake and venom production between a group of wild, recently captured vipers and a group of born and bred captive vipers. In addition, the influence of sex on both parameters was established. The research brought evidence of important differences concerning voluntary food ingestion and venom production between the two groups of animals. However, sex appeared not to significantly influence these parameters, both in wild, recently captured vipers and in born and bred captive vipers. Wild animals rapidly accommodated to the microclimate conditions in captivity and readily accepted food.

Exploitation of viper venom all over the world is mainly due to its usefulness in the fields of pharmaceutical industry and research (Georgescu et al., 1999). Thus, setting up a breeding technology of the sand viper in captivity is needed.

Among the two European viper species ( $V$. ammodytes and $V$. berus) that are being exploited for venom production, venom production is higher in the Vipera ammodytes species, which also rapidly accomodates to captivity (Georgescu et al., 2000). Due to the obvious differences with regard to the dimensions of the venom glands and the shape of the head between wild animals and bred-captive vipers, we hypothesized higher venom productions in the latter as compared to the former. The present study compared the outcome of voluntary feed intake and venom production in two groups of vipers: a group of wild, recently captured sand vipers and another group of born and bred captive sand vipers, respectively.

\section{MATERIAL AND METHODS}

The experiments were carried out at the Vistea farm, Cluj, between 09. 07. 1998 - 22. 09. 1998. Eighteen wild specimens of the Vipera ammodytes ammodytes species were captured by hand during April-May 1998 around Băița, Hunedoara, located in the Occidental Carpatians Mountains. Of the eighteen snakes, ten specimens (five males and females) were selected. None of the wild, recently captured animals died during the experiment.

The five male and five female recently captured vipers were compared with five male and five female born and bred captive animals. The born and bred captive vipers were the offspring of specimens that were captured between 1990-1993, around Băița. We should mention that all our specimens were Vipera ammodytes ammodytes snakes and not intermediary or abnormal specimens, as described by Biella (1983) were observed.

The animals were kept in specially built boxes in a large hall. The temperature inside the hall was about $15-20{ }^{\circ} \mathrm{C}$ during summer and seldom $20{ }^{\circ} \mathrm{C}$, whereas during the cold nights of September, the temperature fell below $15{ }^{\circ} \mathrm{C}$ occasionally. Inside the boxes, at floor level, the temperature varied between $33-35{ }^{\circ} \mathrm{C}$ around the lamp and about $19-20{ }^{\circ} \mathrm{C}$ near the water dish. The upper limit of temperature at the floor level was estimated accordingly to the research of Saint Girons (1975). Thus, vipers could choose the most favorable temperature within $18-35{ }^{\circ} \mathrm{C}$. Large windows assured natural daylight. Water was in constant supply.

The frontal wall of the boxes was made of glass and the other walls of wire, as recommended by Holzberger (1980). The boxes were high enough not to allow the escape of the animals, so no cover was built. The floor of all boxes was made of $2 \mathrm{~mm}$ thick metal plate and covered by a $3-5 \mathrm{~cm}$ layer of small river stones and a few larger stones in order to create similar conditions to those from the vipers natural habitats (Luiselli, 1996).

At the beginning of the study all animals were weighted and individualized. There was no significant difference in the mean body weight of the two groups at the start of the experiment. Before the study started, the wild animals were given an adaptation period of 2 months. During accommodation, vipers were milked bimonthly. At the beginning of the study, wild animals were tested at least once for voluntary food ingestion. The vipers were feed white laboratory mice in constant supply. In order to avoid venom loss, the mice were previously killed. Feeding started after venom collection was performed. However, to avoid regurgitation of food, feeding was stopped in all animals 3 days before the next venom collection. The follow-up period ranged from April to September 1998. Snakes were milked every two weeks and the venom was collected and quantified.

Results were expressed as mean \pm S.E.M. (standard error of mean) of mean venom production/venom collection. The Student's $t$ test was used for statistical analysis of the results.

\section{RESULTS AND DISCUSSION}

Several morphological differences were noticed with regard to the dimensions of the venom glands and the shape of the head between the two groups of vipers. Vipers bred in captivity presented large 
venomous glands and a square-shaped head, the length of the head (defined by the distance between the top of the muzzle and the base of the skull) being approximately equal to the width. Both the male and female wild vipers rapidly accepted the microclimate conditions in captivity and food. The wild animals had significantly smaller venomous glands and a rectangular-shaped head (Figure 1).

Figure 1: The differences with regard to the shape of the head and development of venomous glands

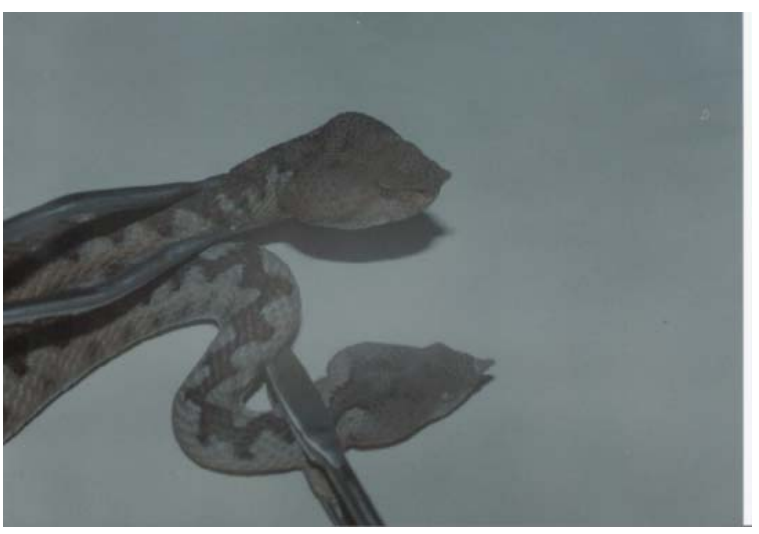

At the end of the study, the wild female vipers had a mean weight of $125.20 \mathrm{~g}$ and no difference was obtained as compared to the mean weight of $121.80 \mathrm{~g}$ at start of the experiment $(p>0.05)$. Wild male specimens had a mean weight of $114.00 \mathrm{~g}$ at start of the study and of $118.60 \mathrm{~g}$ at end of the study $(\mathrm{p}<0.01)$ (Table 1). Concerning the outcome in body weight, this was not an objective of the present study, since the results were similar to those recorded during the active cycle of 1997 (Georgescu et al., 2000).

In their natural habitats, both male and female viper, ingest rather small quantities of prey (Luiselli,
1996). During an active cycle (from spring to autumn), males will accomplish a mean prey ingestion of about $113 \%$ of their initial weight (at the moment when hibernation is ended) and females will record a mean prey ingestion of about $117 \%$ of their initial weight. Thus, a small weight increase of $4.39 \%$ from their initial weight is recorded in these animals (Saint Girons, 1979), probably representing the ratio necessary to maintain a basal metabolic rate. The present experimental work confirmed this supposition, with a lower voluntary food ingestion in wild animals as compared to bred captive animals, even though no limitations concerning the quantities of forage to be offered were established. During the period of time when voluntary feed intake was analyzed, mean feed intake/interval of feed intake (interval of feed intake $=$ total amount of feed consumed between two successive venom collections) accomplished by wild females was 10.86 g, or about $40 \%$ lower, as compared to the feed intake/interval of feed intake recorded by born and bred captive females, of 16,48 $\mathrm{g}(\mathrm{p}<0.05)$ (Table 2).

In males, mean feed intake/interval of feed intake was of $11.43 \mathrm{~g}$ in wild vipers and of $15.68 \mathrm{~g}$ in bred captive vipers $(\mathrm{p}<0.01)$ (Table 3$)$. Thus, the quantity of ingested food was about 30\% lower in wild animals as compared to animals bred in captivity. No significant difference concerning voluntary food ingestion between males and females was detected in wild sand vipers (Table 1). Various factors may explain the differences between the two groups of animals concerning voluntary food ingestion: the maintenance of natural biorhythms in wild animals; captivity and regular milking of vipers may act as stress factors for these animals; increased food necessity due to higher venom production in born and bred captive vipers.

Table 1: Weight, voluntary feed intake and venom production of wild, recently captured Vipera ammodytes ammodytes $(\mathbf{X} \pm \mathbf{s}, \mathbf{g})$

\begin{tabular}{|l|r|r|r|r|}
\hline \multicolumn{1}{|c|}{ Issue } & Females & \multicolumn{1}{c|}{ Males } & D & p \\
\hline Weight at start of the study & $121,80 \pm 4,46$ & $114,00 \pm 5,71$ & 7,80 & $\mathrm{~ns}$ \\
\hline Weight at end of the study & $125,20 \pm 3,48$ & $118,60 \pm 5,65$ & 6,60 & $\mathrm{~ns}$ \\
\hline Voluntary feed intake/interval of feed intake & $10,86 \pm 1,76$ & $11,43 \pm 1,10$ & $-0,57$ & $\mathrm{~ns}$ \\
\hline Venom production & $0,13 \pm 0,00$ & $0,12 \pm 0,00$ & 0,01 & $\mathrm{~ns}$ \\
\hline
\end{tabular}

Table 2: Voluntary feed intake and venom production of females $(\mathbf{X} \pm \mathbf{s}, \mathbf{g})$

\begin{tabular}{|l|r|r|r|}
\hline \multicolumn{1}{|c|}{ Issue } & Bred-captive females & Wild females & \multicolumn{1}{c|}{ D } \\
\hline Voluntary feed intake/interval of feed intake & $16,48 \pm 1,53$ & $10,86 \pm 1,76$ & 5,62 \\
\hline Venom production & $0,29 \pm 0,02$ & $0,13 \pm 0,00$ & $<0.05$ \\
\hline
\end{tabular}

Table 3: Voluntary feed intake and mean venom production of males $(\mathbf{X} \pm \mathbf{s}, \mathbf{g})$

\begin{tabular}{|l|r|r|r|r|}
\hline \multicolumn{1}{|c|}{ Issue } & Bred-captive males & \multicolumn{1}{c|}{ Wild males } & \multicolumn{1}{c|}{ D } & \multicolumn{1}{c|}{ p } \\
\hline Voluntary feed intake/ interval of feed intake & $15,6800 \pm 0,6901$ & $11,4300 \pm 1,1000$ & $4,2500^{* *}$ & $<0.01$ \\
\hline Venom production & $0,2701 \pm 0,0189$ & $0,1224 \pm 0,0047$ & $0,1477 * * *$ & $<0.001$ \\
\hline
\end{tabular}


Venom was collected from each specimen every two weeks and mean venom production was calculated. Wild sand vipers had a mean venom production of $0.1361 \mathrm{~g}$ for females and $0.1224 \mathrm{~g}$ for males, being significantly lower to the mean venom production of bred captive sand vipers, of $0.2920 \mathrm{~g}$ for females and of $0.2701 \mathrm{~g}$ for males, respectively (Tables 2 and 3). Thus, mean venom production was about $113 \%$ higher in females $(p<0.01)$ and about $120 \%$ higher in males $(\mathrm{p}<0.001)$ from bred captive vipers, as compared to wild animals. This may be due to:

- Permanent stimulation of venomous glands in bred captive animals, due to the fact that their venom is periodically collected in order to generate profit;

- Complete evacuation of venomous glands when venom is collected in the laboratory, whereas in nature, vipers never will entirely evacuate the glands with one bite;

- Selection for reproduction those animals showing increased venom production in captivity.

No significant difference concerning venom production between males and females was detected in wild sand vipers (Table 1). Low venom production in wild sand vipers might be physiological, however no data with regard to venom production of Vipera ammodytes ammodytes in their natural habitats was found in the literature. On the other hand, factors as captivity and manipulation of animals during the process of milking of animals might influence venom secretion of these animals.

\section{CONCLUSIONS}

1. Mean voluntary food ingestion in wild, recently captured sand vipers is about $40 \%$ lower in females and $30 \%$ in males, respectively, in comparison to born and bred captive animals.

2. Mean venom production in wild, recently captured vipers as compared to born and bred captive animals appears to be about $113 \%$ lower in females and about $120 \%$ lower in males, respectively.

3. In both groups of animals, females constantly had higher venom productions as compared to males.

\section{REFERENCES}

Biella, H. J. (1983): Intermediäre und abnorme Sandvipern aus der Herpetologischen Sammlung des Staatlichen Museums für Tierkunde Dresden (Reptila: Serpentes: - Viperidae). - Zool. Abh. Staatl.Mus.Tierk., Dresden, 38. 14. 237-245.

Georgescu, B.-Sălăjan, Gh.-Iozon, D.-Mierliță, D.-Odagiu, A. (2000): Studies on voluntary food ingestion of white laboratory mice in Vipera ammodytes snakes, during an active season. Vol. Nat. Simp. „Achievements and Expectations in Animal Husbandry and Biotechnologies”. FZB Cluj-Napoca, XXVI. 247-251.

Georgescu, B.-Sălăjan, Gh.-Iozon, D.-Odagiu, A.-Mierliță, D. (1999): Applied bioecology. Snakes venom. Composition, farmacodynamics and commercial value. Vol. Simpozionului Ştiințific Omagial „80 ani de Învătământ universitar românesc la Cluj-Napoca”,
Facultatea de Zootehnie şi Biotehnologii agricole, ClujNapoca, Editura OSAMA Cluj-Napoca, XXIV. 164-168.

Holzberger, H. (1980): Ergänzende Angaben zur Haltung und Zucht von Vipera ammodytes. - Herpetofauna, Ludwigsburg Osweil, 2. 9. 32.

Luiselli, L. (1996): Food habits of an alpine population of the sand viper (Vipera ammodytes). Journal of Herpetology, 30. 1. 9294.

Saint Girons, H. (1975): Observations préliminaires sur la thermorégulation des Viperes d'Europe. Vie et Milieu, 25. 137-168.

Saint Girons, H. (1979): Les cycles alimentaires des Viperes européennes dans des conditions seminaturelles. Ann. Biol. Anim. Bioch. Biophys., 19. 125-134. 